\title{
CURRENTS OF THE CONTINENTAL SHELF AND UPPER SLOPE OF TASMANIA
}

\author{
by George Cresswell
}

(with seven text-figures; figure 4 in colour)

Cresswell, G., 2000 (31:v): Currents of the continental shelf and upper slope of Tasmania. In Banks, M.R. \& Brøwn, M.J. (Eds): TASMANIA AND THE SOUTHERNOCEAN. Pap. Proc. R. Soc. Tasm. 133(3): 21-30. https://doi.org/10.26749/rstpp.133.3.21 ISSN 0080-4703. CSIRO Division of Ocernography, GPO Box 1538, Hoban, Tasmania, Australia 7001.

Satellite-tracked drifters, satellite imagery, a research vessel and moorings in the waters of Tasmania, excluding Bass Strait, revealed a southward current, sometimes called the Zeehan Current, on the outer continental shelf of western Tasmania. The current has a peak speed in winter, when it reaches around southern Tasmania as far north as Schouten Island before veering southeastward under the influence of the East Australian Current. In summer, the Zeehan Current is weaker, while the East Australian Current is stronger and overshoots southward past Tasmania by about $200 \mathrm{~km}$, entraining the Zeehan Current in the process. Off western Tasmania, well seaward of the Zeehan Current, the residence time for satellite-tracked drifters was as much as one year. More than $200 \mathrm{~km}$ south of Tasmania in summer there was weak flow to the west. Eleven of 13 satellite drifters released in Tasmanian waters eventually meandered eastward towards New Zealand, with a travel time of over 18 months from the time of release.

Key Words: sea-surface temperatures, Zeehan Current, East Australian Current, long-term drift, Tasmania.

\section{INTRODUCTION}

In some ways Tasmania can be thought of as set in or influenced by three oceans: the Pacific on the east, the Indian on the west and the Southern on the south. Of course, this is oversimplified, but it does give some clues as to the potential complexity of the currents and water properties in the region. As compared to other Australian waters, those of Tasmania have been subject to very little study. Even the maritime approach of assembling ship drifts to produce monthly current charts was thwarted by lack of data over extensive areas west of Tasmania (Koninklijk Nederlands Meteorologisch Institut 1949).

Wood (1954) interpreted distributions of dinoflagellates to postulate that a current flowed eastward from Cape Leeuwin to King Island and suggested that confirmation came from the finding of warm-water turtles on the west coast of Tasmania. He pointed out that such a current was in keeping with the current atlases presented by Schott (1935). Drift bottle studies off western Tasmania (Vaux \& Olsen 1961) suggested that in winter an eastward current from South Australia split offshore from western Victoria, with part entering Bass Strait and part running southward along western Tasmania. This branch then turned and ran northward off eastern Tasmania. In summer, drift bottle releases/recoveriessuggested a northward current off western Tasmania that was joined by water from Bass Strait to flow to the Great Australian Bight. Newell (1961) felt that the seasonal alternation of the circulation was due to the northsouth migration of the Australian atmospheric high pressure zone. The southerly winds in summer, he suggested, probably drove Subantarctic water $\left(14^{\circ} \mathrm{C}, 35.0 \mathrm{psu}\right)$ northward off western Tasmania. However, at the same time, he felt that subtropical water (>35.5 psu) from the southern Indian Ocean reached western Tasmania in the westwind drift, causing summer strandings of subtropical and tropical fauna, such as Physalia. In a later paper, Newell (1974) found that the upper waters encountered off southeastern Tasmania in winter were derived from the region to the west and northwest of Tasmania, once again pointing to southward flow off western Tasmania in winter.
Temperature sections between Melbourne and Antarctica in summer showed warm southward flow above the continental slope at the western entrance to Bass Strait (Edwards \& Emery 1982), and this was named the Zeehan Current by Baines et al. (1983). It was thought to be about $40 \mathrm{~km}$ wide and permanently southward, rather than seasonally reversing as claimed by Newell (1961) and Vaux \& Olsen (1961). Baines et al. (1983) had no information on the currents of the continental shelf. The first long-term moored current meter data were obtained by Lyne \& Thresher (1994) at four sites across the western Tasmanian shelf and slope between June and November 1988. The currents were consistently southward and strong at the shelf edge, averaging $0.3 \mathrm{~ms}^{-1}$. Off eastern Tasmania, Harris et al. (1987) concluded that the seasonal and interannual variability could be explained by the varying location of the subtropical convergence off the central eastern Tasmanian coast.

With a view to better understanding the relationship between coastal, shelf and open ocean currents, we released 13 satellite-tracked drifrers with drogues at $15 \mathrm{~m}$ depth on the continental shelf around Tasmania from 1991-94 and we examined satellite sea-surface temperature images of the region. In March and December 1997, we carried out two ship surveys with the RV Franklin along a number of transects from nearshore to the $2000 \mathrm{~m}$ isobath to the west, south and east of Tasmania. Two acoustic Doppler current profilers (ADCPs) were moored at the 100 and $200 \mathrm{~m}$ isobaths off western Tasmania for 11 months from March 1997. The initial results of this work are discussed in this paper.

\section{INSTRUMENTATION}

East Australian Current satellite-tracked drifters have a cylindrical surface unit ( $0.6 \mathrm{~m}$ long by $0.2 \mathrm{~m}$ diam.) with a $0.5 \mathrm{~m}$ whip antenna. The unit floats $70 \%$ submerged and is attached by a $4 \mathrm{~mm}$ diameter cable to a small subsurface float and thence to a "holey sock" drogue that is $5 \mathrm{~m}$ long and $1 \mathrm{~m}$ diam. The centre of the drogue is at a depth of $15 \mathrm{~m}$. 
The surface unit measures sea temperature, battery condition and tilt. It transmits this information and an identification code at $410 \mathrm{MHz}$ every 1.5 minutes for its first week adrift, and thereafter one day in three to save power and reduce tracking charges. NOAA satellites carrying CLS-Argos systems pass over at least six times per day and fix the drifter positions to better than $1 \mathrm{~km}$. The drifters were manufactured by Moonraker Technology Pty Ltd in Hobart.

The satellite images in this paper came from Advanced Very High Resolution Radiometers (AVHRRs) aboard NOAA satellites, and the data were received at stations at Alice Springs and Darwin. The images were processed to give sea-surface temperature estimates, using the method of McMillin \& Crosby (1984), and remapped to a standard cartographic projection (Nilsson \& Tildesley 1986). The images include a $1^{\circ} \times 1^{\circ}$ latitude-longitude grid, and they have a temperature scale along their tops. Clouds appear white in the images.

RV Franklin's instrumentation included a Neil Brown CTD, Turner fluorometer, and Niskin bottle rosette for water sampling, a thermosalinograph, and a RD Instruments $150 \mathrm{kHz}$ Acoustic Doppler Current Profiler (ADCP) that continuously measured current profiles, using a bottomtrack mode when the water depth was less than $-300 \mathrm{~m}$ and the Global Positioning System (GPS) in the deeper waters. Note that the ship's ADCP cannot measure currents in the lowest $15 \%$ of the water column. This is because of side lobes in the transducer radiation patterns. We use practical salinity units (International Oceanographic Tables 1981) and Universal Time; Australian Eastern Standard Time is UT +10 hrs. The ship's weather station recorded wind speed and direction and corrected these for ship's speed and direction.

The paths followed by RV Franklin on the two voyages are shown in figure 1. The stations occupied on FR3/97 were repeated on FR10/97 as weather permitted. A change from bad to good weather near the end of FR10/97 allowed a transect to be done from King Island.

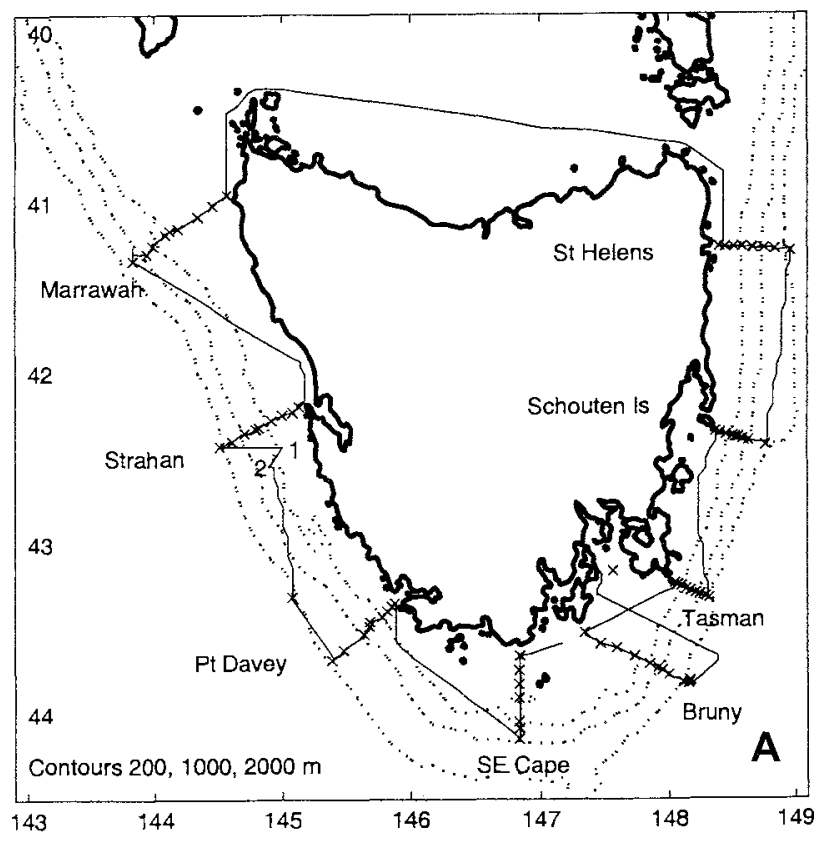

The moored $150 \mathrm{kHz}$ ADCPs were mounted in floats several metres above the bottom at the 100 and $200 \mathrm{~m}$ isobaths off western Tasmania. These instruments measured currents from near the bottom to $15 \mathrm{~m}$ and $30 \mathrm{~m}$ from the surface respectively.

\section{RESULTS}

\section{Satellite-tracked Drifters}

Of 13 drifters, one was released off eastern Tasmania in August 1991; three were released off the same coast in May 1992; three off western Tasmania in July 1992; three off southern Tasmania in November 1992; and three off western Tasmania in January 1994. We will not discuss all the drifter tracks in detail - rather, while making general comments about all the drifters, we will concentrate on drifters that were released off western Tasmania and later summarise our findings in a simple schematic for the near-surface currents in summer and winter.

The drifters released off western Tasmania (fig. 2 ) revealed a southward current on the continental shelf in both winter and summer. The drifters that were beyond the shelf generally did not detect this current. In winter the drifters from the west were carried up the eastern Tasmanian continental shelf, sometimes as far as Schouten Island, before coming under the influence of the East Australian Current and being swept SSE. In summer the drifters only went as far as the southern end of Tasmania before encountering the southern extension of the East Australian Current. This carried them southward and into eddies. Figure 2 shows, also, how one drifter from the east moved westward to the south of Tasmania and eventually was entrained into the Zeehan Current. Several other drifters behaved similarly.

Eleven of the 13 drifters left Tasmanian waters to follow meandering paths tending ENE towards New Zealand,

FIG. 1 - The station positions and the paths followed by the RV Franklin: (A) 19-27 March and (B) 1-9 December 1997. The locations of the two moored Acoustic Doppler Current Profilers are marked as 1 and 2 on the $100 \mathrm{~m}$ and $200 \mathrm{~m}$ isobaths respectively.

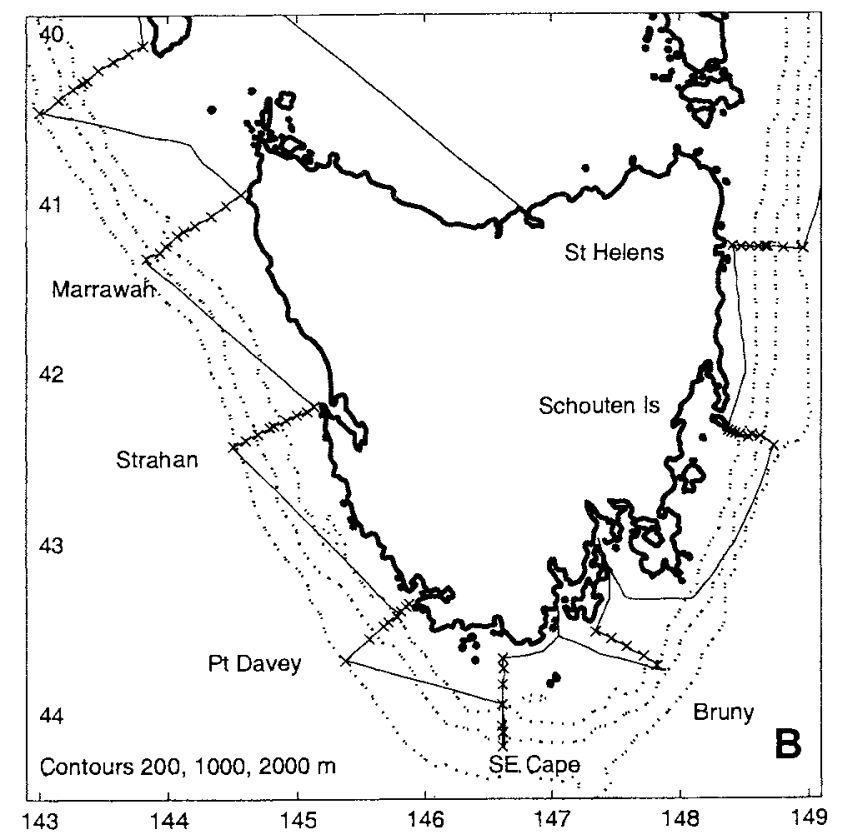


A
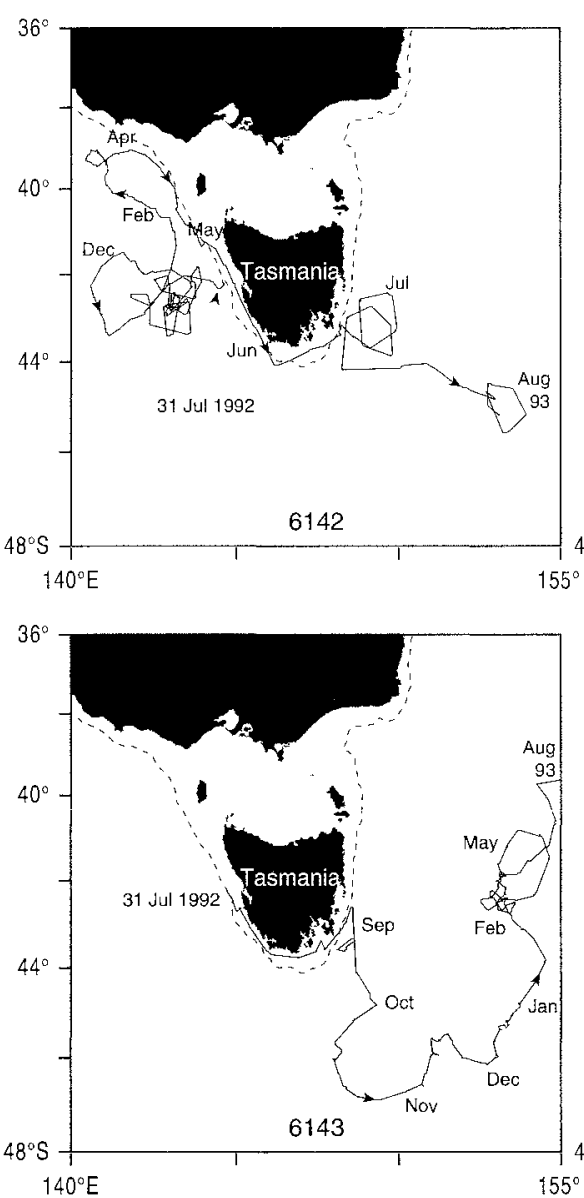

B
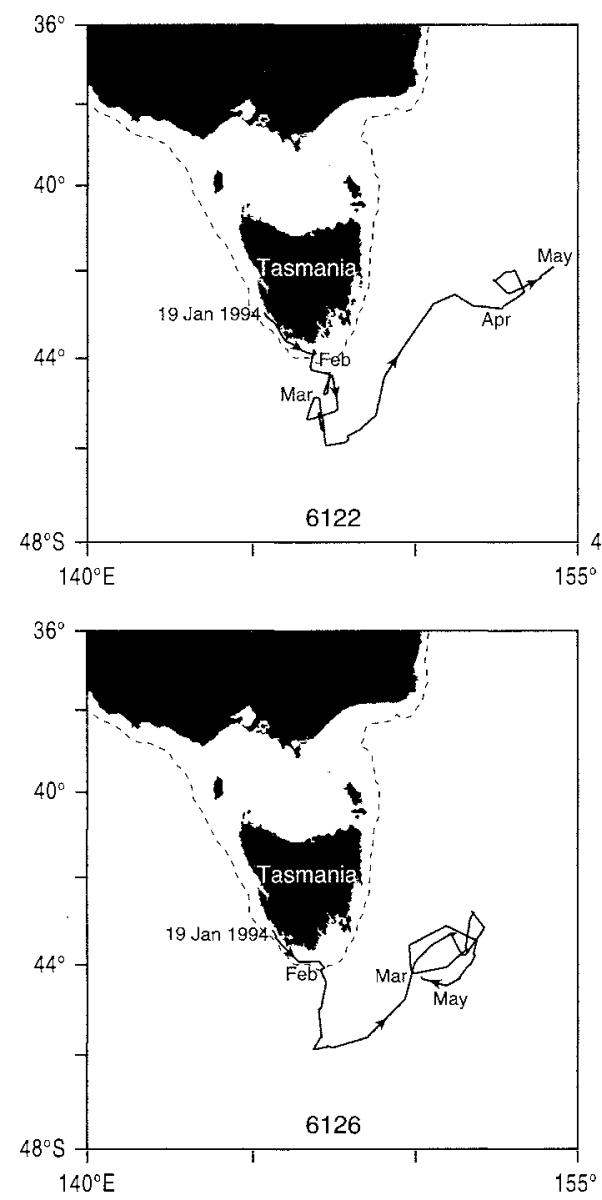
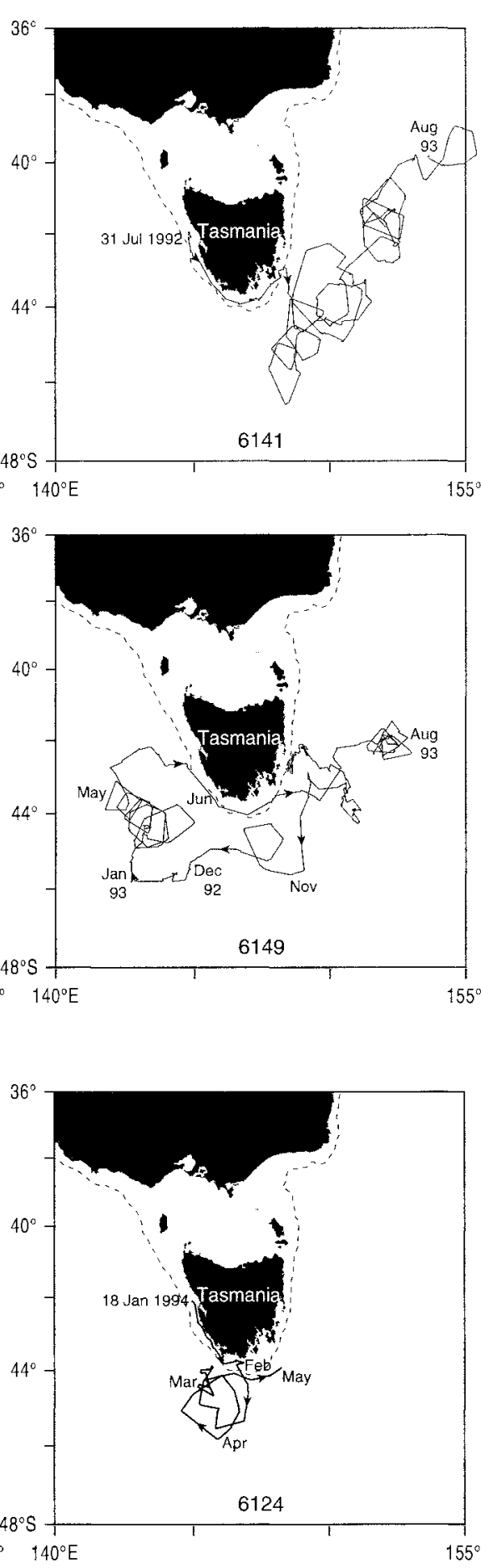

FIG. 2 - (A) The tracks of four drifters, showing the influence of the Zeehan Current in taking continental shelf water from western to eastern Tasmania in winter. This flow reaches almost to Schouten Island on the east coast before part of it is entrained into the East Australian Current. (B) The tracks of three drifters released off western Tasmania in summer, showing the Zeehan Current to be flowing on the continental shelf at that time as well as in winter. The Zeehan Current only reached southern Tasmania before being entrained into the East Australian Current and swept $-200 \mathrm{~km}$ southward. 
probably south of the Subtropical Front, and four examples are shown in figure 3 . These were all within 200 $\mathrm{km}$ of New Zealand before their electronics failed 16, 20, 22 and 32 months respectively after they were released. These travel times will be relevant when considering the likelihood of colonisation of New Zealand by Tasmanian marine creatures.

\section{Winter and Summer Satellite Sea-surface Temperature Images}

Satellite sea-surface temperature images reflect the behaviour of the drifters. A winter image (fig. 4A) shows the Zeehan Current as warm water $\left(-12^{\circ} \mathrm{C}\right)$ coming southward down the western Tasmanian continental shelf, around to eastern Tasmania, and then northward at least as far as Maria Island before encountering the East Australian Current. Note the eddies to the west of King Island, the offshoots of warm water off southwestern Tasmania, and the extensive cold regions in southern and eastern Bass Strait.

The summer image (fig. $4 \mathrm{~B}$ ) shows the Zeehan Current reaching southern Tasmania before being entrained into the East Australian Current, which overshoots $200 \mathrm{~km}$ past the island. The image is within the period covered by the drifter tracks in figure $2 \mathrm{~B}$ and it delineates the same warm eddy as the drifters.
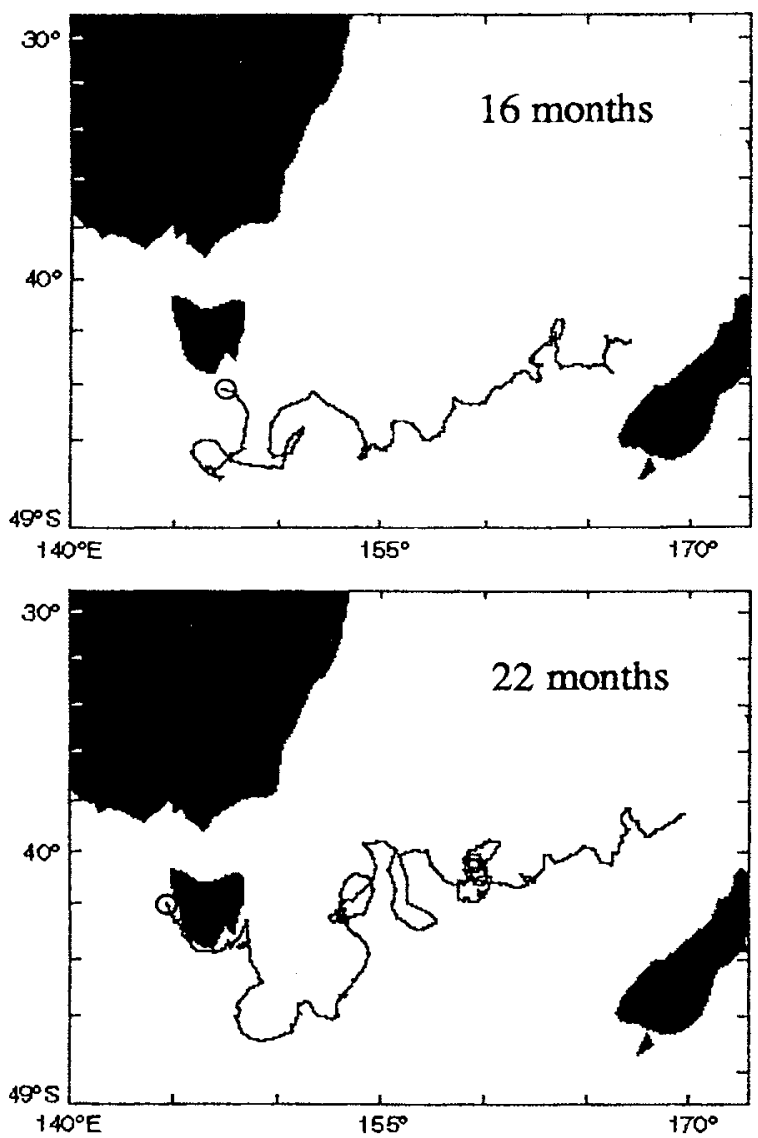

\section{Observations from the RV Franklin in March and December 1997}

Not all data can be included here. We discuss sections of temperature and salinity from the CTD and north-south and east-west velocity components from the ADCP off $S t$ Helens, Bruny Island and Strahan (fig. 5A-C). The ADCP data showed the East Australian Current in the open ocean off St Helens and Bruny Island to have speeds of 0.3 to $0.4 \mathrm{~ms}^{-1}$ southward. On the St Helens line, the surface waters of the East Australian Current were salty and warm $\left(>35.4 \mathrm{psu},>16^{\circ} \mathrm{C}\right)$ and they extended in across the shelf, in keeping with the $0.1 \mathrm{~ms}^{-1}$ westward current component detected by the ADCP. There was a northward component to the flow at the upper continental slope and over the shelf.

The warm salty East Australian Current waters were only evident at the extreme seaward end of the Bruny Island line in March. The current on the shelf was to the northeast and it carried low salinity water $(<35 \mathrm{psu})$ from southern and, perhaps, western Tasmania. We suggest that this was the extension of the Zeehan Current and that it had been freshened by terrestrial runoff from western Tasmania.

Off Strahan in March, the southward-flowing Zeehan Current prevailed over most of the line and reached speeds of $0.2 \mathrm{~ms}^{-1}$. The salinity structure was complicated because of the influence of low salinity outflow from Macquarie Harbour at the surface; a core of high salinity water (35.2 psu) in the thermocline that extended across the shelf at 50-80 $\mathrm{m}$ depth, perhaps from the Great Australian
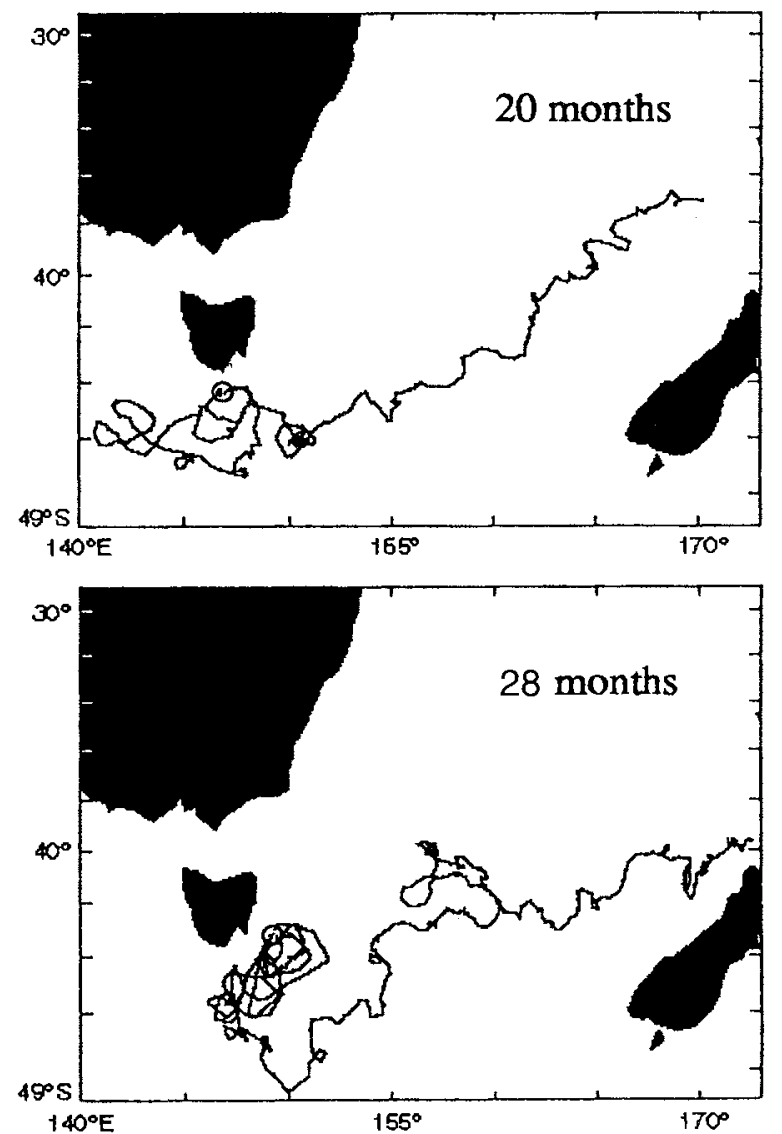

FIG. 3 - The paths of four (of 11) drifters that went from various Tasmanian release sites (small circles) over towards New Zealand. Their lifetimes were: November 1992-March 1994; November 1992-July 1994; July 1992-May 1994; and August 1991-December 1993. 

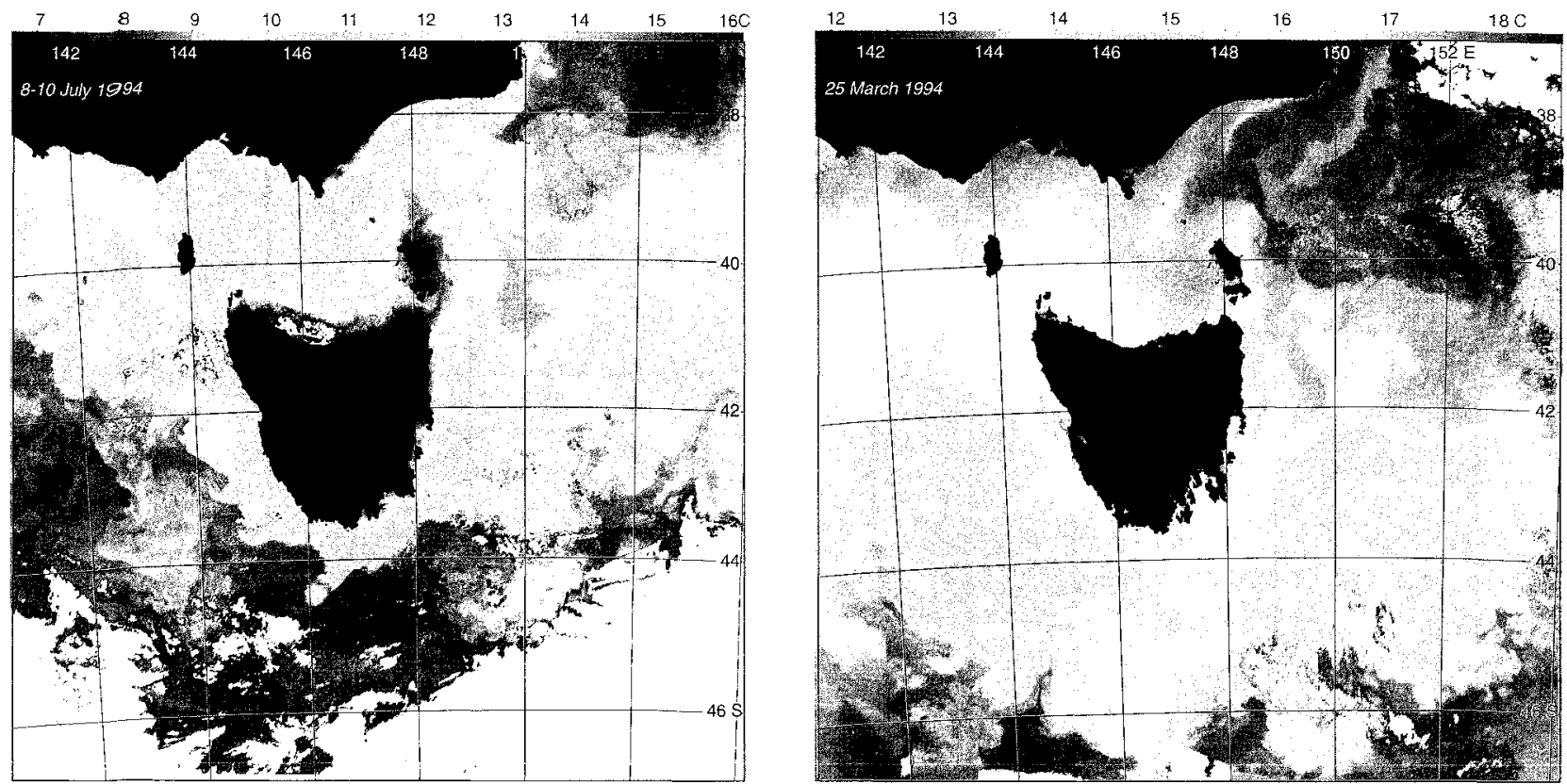

$F I G .4$-Winter $(A)$ and summer $(B)$ satellite sea-surface temperature images from the NOAA11 satellite. Red is warm ranging through blue, which is relatively cold. The temperature scale is across the top of the images. Clouds are white.

Bight; and a stratum of relatively high salinity water (>34.9 psu) between 80 and $170 \mathrm{~m}$ depth that extended into the shelf from the open ocean. The temperature structure was less informative, although the thermocline could be seen to be stronger and shallower than off St Helens. The Macquarie Harbour plume did not have a noticeable temperature signature and so would not be detected by infrared sensors on satellites.

The conditions along the St Helens line in December were somewhat surprising in that, while the upper waters of the outer shelf and open ocean were salty and warm, typical of the East Australian Current, the currents there were northeastward - with a strong subsurface core of $0.4 \mathrm{~ms}^{-1}$ northward near the upper continental slope. We conclude that this was a meander on the edge of a stronger flow of East Australian Current water. On the shelf, the flow was southwestward, and this appears to have driven upwelling of relatively cool and fresh water $\left(<15^{\circ} \mathrm{C}\right.$, $<35.2 \mathrm{psu}$ ) to the surface on the inner shelf.

Inclement weather stopped the December Bruny Island line near the shelf edge. The currents there were southeastward at $0.4-0.5 \mathrm{~ms}^{-1}$. Curiously, there was no evidence of the warm salty waters of the East Australian Current. On the inner shelf (excluding very near the shore) the flow was northeastward as in March, bringing low salinity water $(<35)$ from southern and western Tasmania.

The December Strahan line revealed a narrower and slightly stronger Zeehan Current flow than in March. It was strongest at the upper continental slope and extended deeper than the $300 \mathrm{~m}$ depth range of the ADCP. As in March, the salinity section revealed the Macquarie Harbour outflow; a salty ( $>35.1 \mathrm{psu}$ ) intrusion of, perhaps, Great Australian Bight water on the continental shelf; and a stratum of relatively salty water ( $>35 \mathrm{psu}$ ) in the upper waters of the open ocean that reached into the shelf. The thermodine was much weaker than in March.

\section{The ADCPs Moored at the 100 and $200 \mathrm{~m}$ Isobaths near Strahan}

The current vector time series (fig. 6) present measurements averaged over the top, middle and bottom thirds of the water column, neglecting the uppermost 15\% (David Griffin, pers. comm.). The shelf edge $(200 \mathrm{~m})$ instrument recorded a persistent southward flow that peaked in June. Northward flows were rare. The shelf instrument $(100 \mathrm{~m})$ also showed predominant southward flow in May/June, but the flow was variable at other times. Of interest, the temporal features of the currents recorded at both instruments showed some consistency through the water column.

The bottom temperatures recorded by the instruments had broad peaks in the winter months. Taken together, the current and temperature records suggest the southward flow in winter of a deep mixed current that is stronger at the shelf edge than nearer to shore. The variability in temperature was larger at the shelf edge instrument, perhaps because of meandering of the current. The largest variability occurred in early July, when the current at the outer site had decreased to very low values, supporting the suggestion of meandering.

The time series of wind resolved along the coast, negative southward, suggests that there may be a loose relationship between it and the current at the $100 \mathrm{~m}$ site. We would expect a stronger relationship nearer the coast. 
A St Helens March 1997 stns 37-45

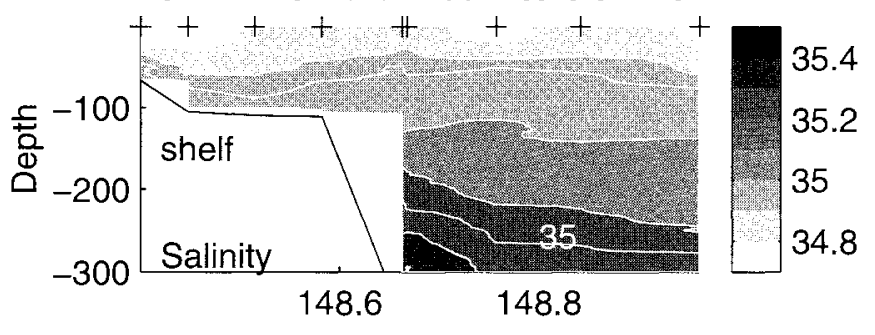

St Helens December 1997 stns 5-12
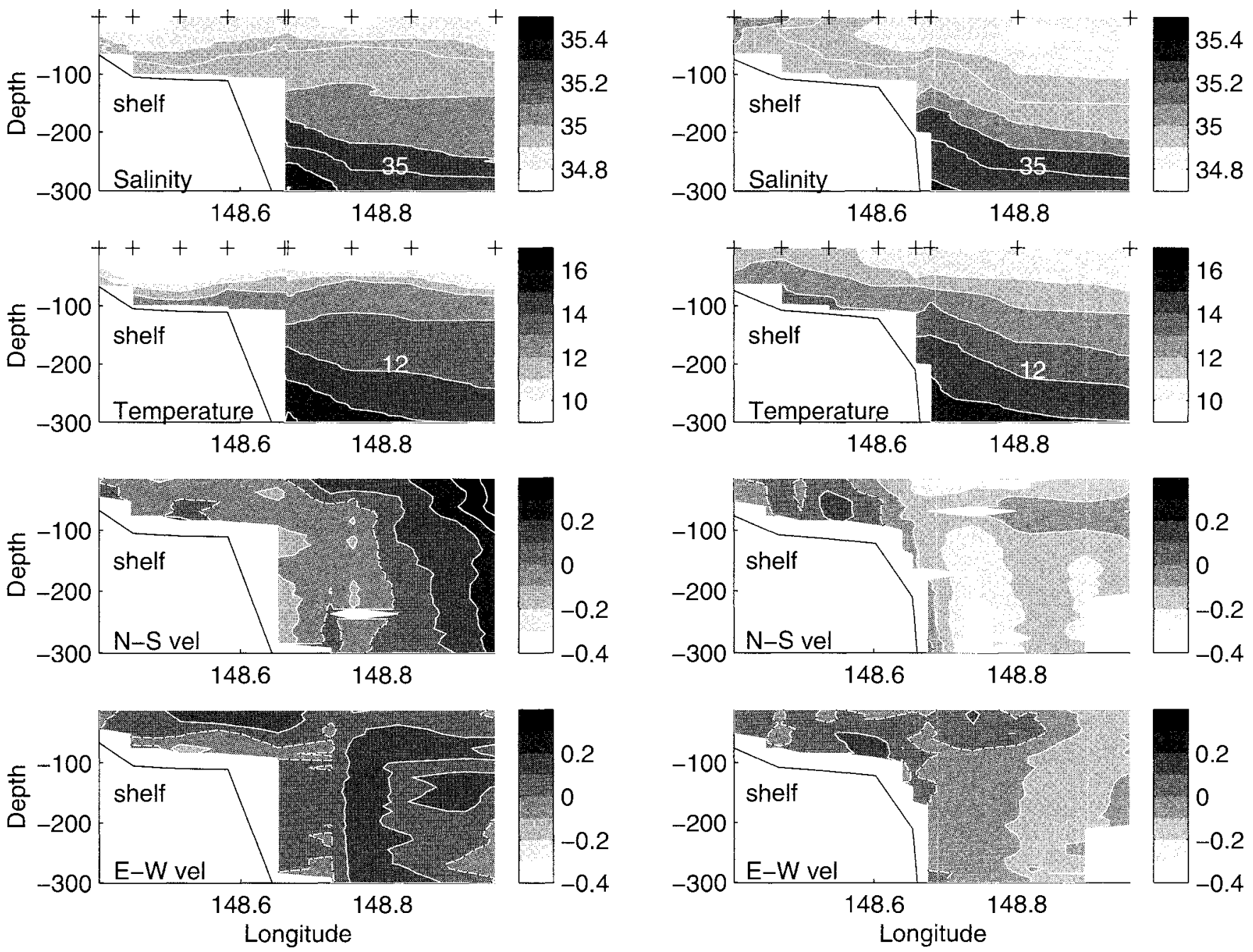

FIG. 5(A-C) Sections of salinity, temperature, and north-south and east-west current components down to $300 \mathrm{~m}$ at the St Helens, Bruny Island, and Strahan lines in March and December 1997. Northward and eastward flow in the current plots are positive (lighter shading) and the dashed lines mark zero. 

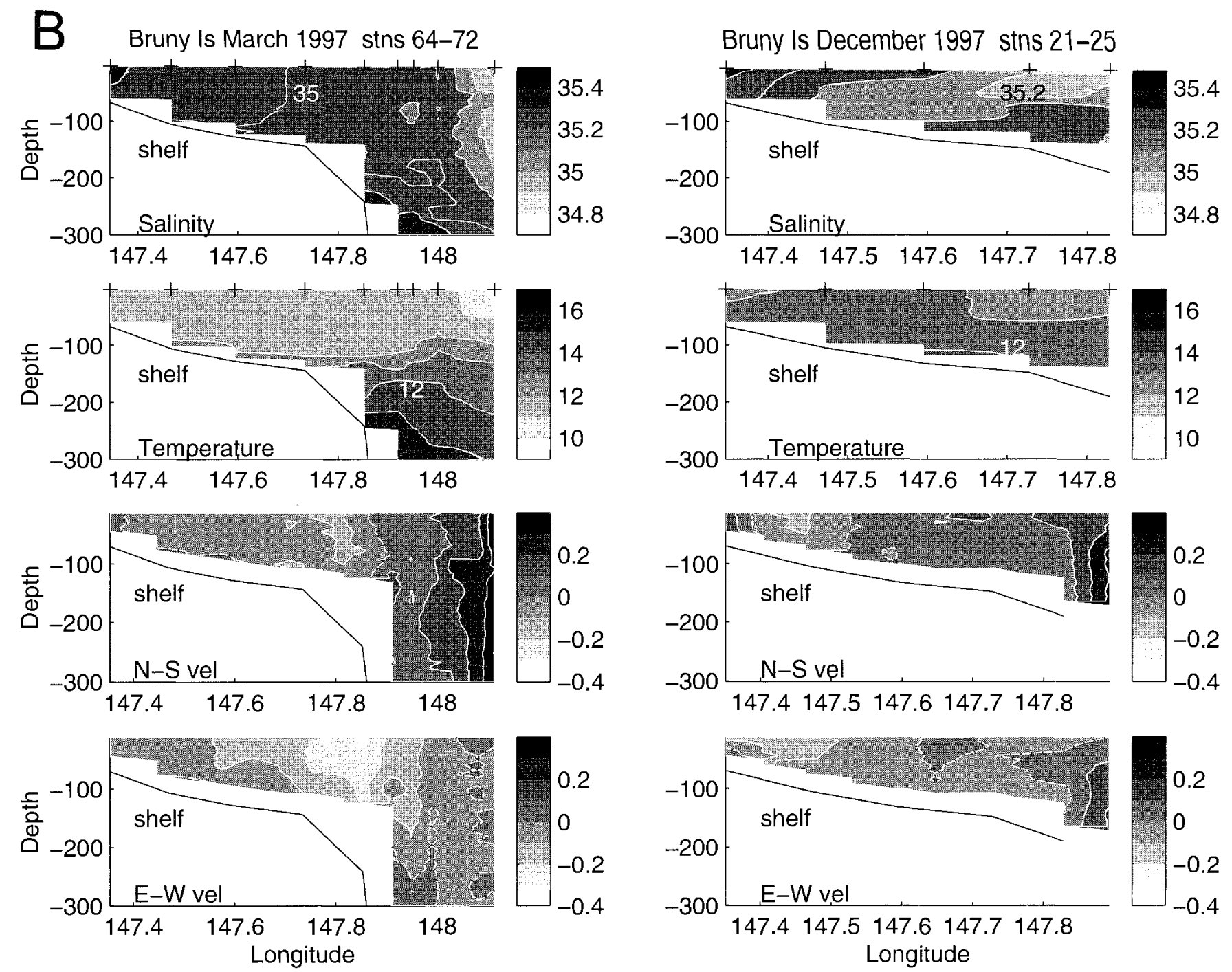
C Strahan March 1997 stns 19:27
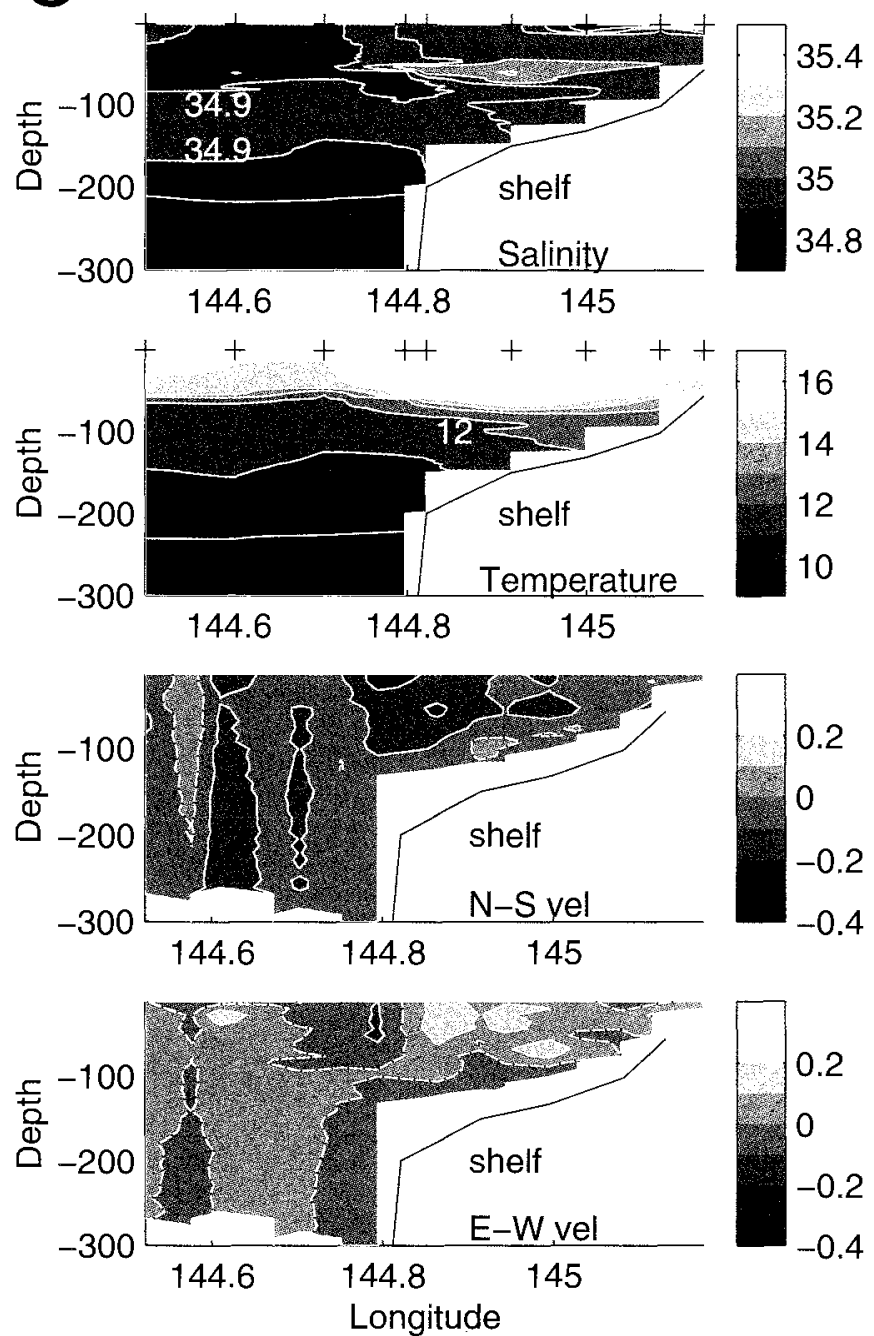

Strahan December 1997 stns 41-49
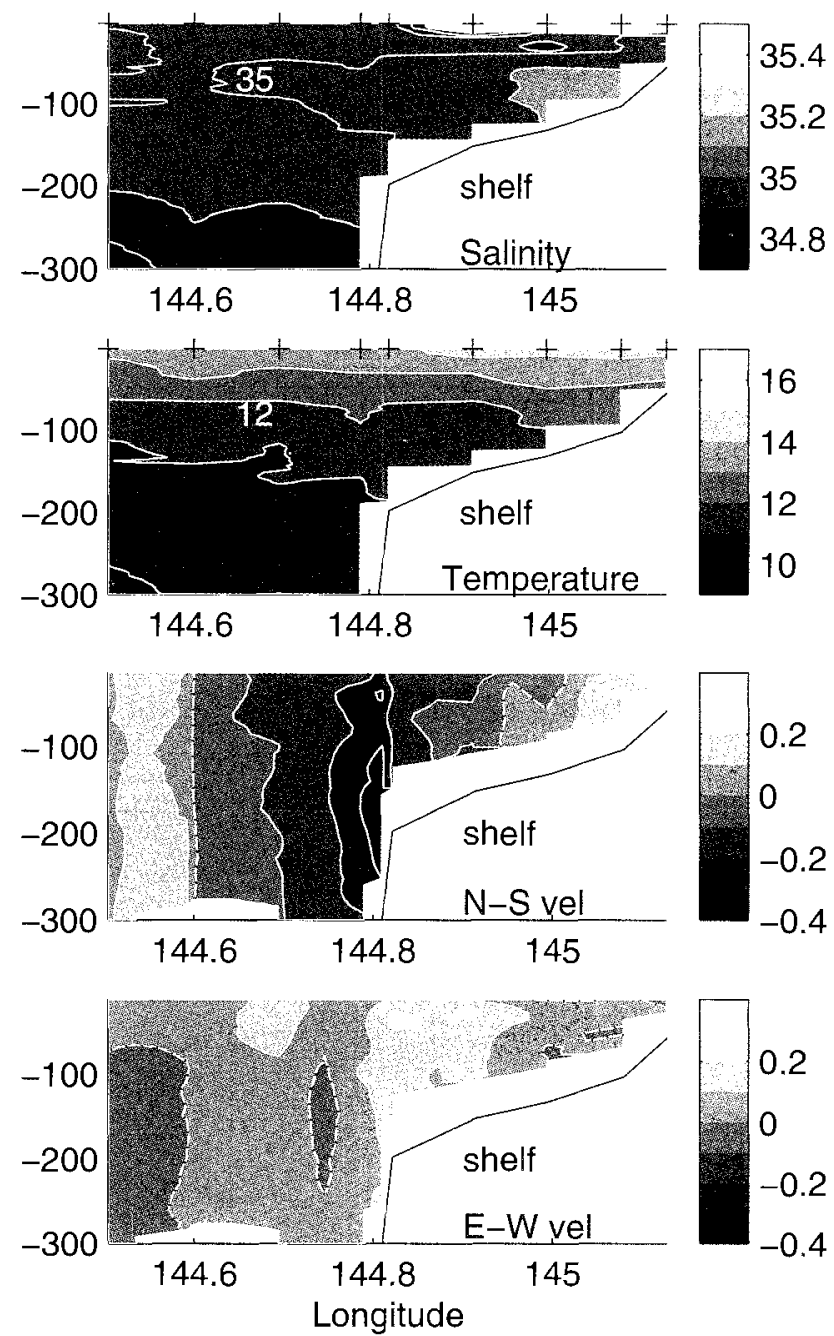

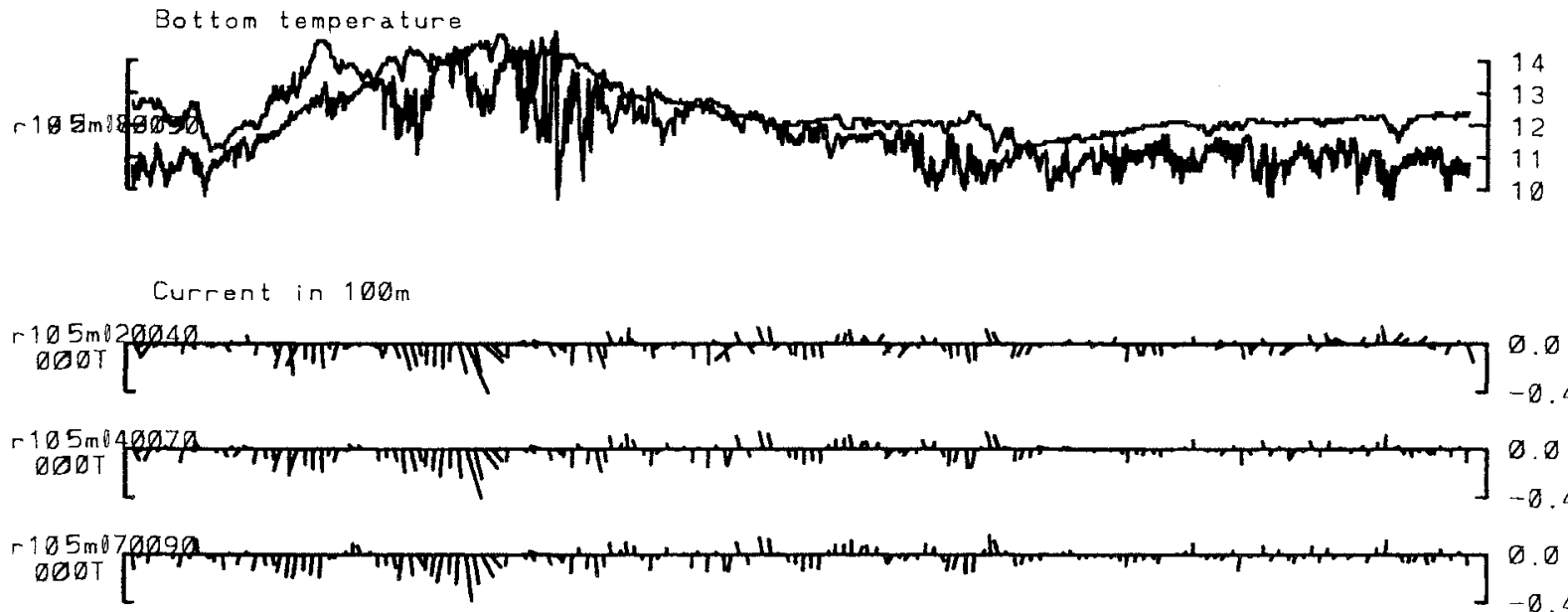

Current in $200 \mathrm{~m}$

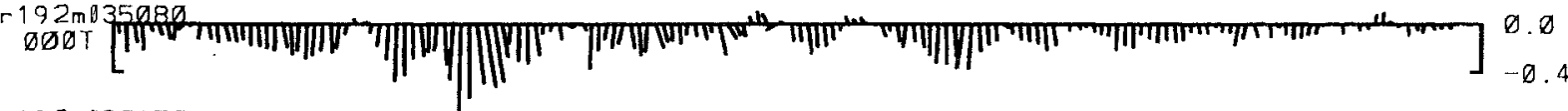

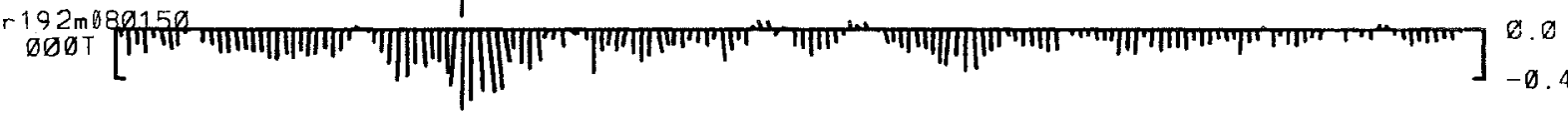

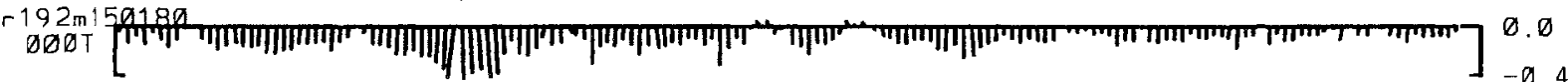

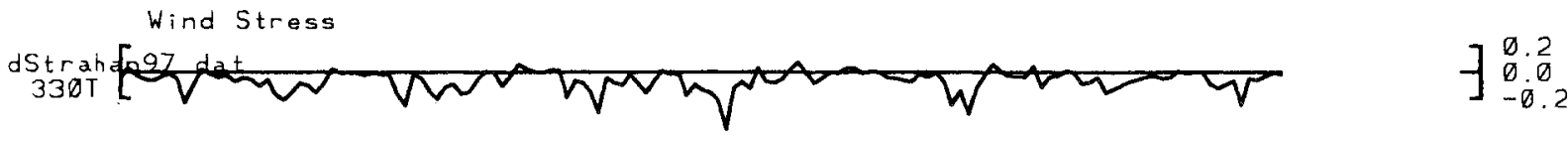

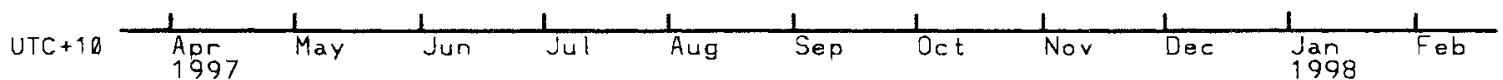

FIG. 6- Bottom temperatures and current vector time series measured with Acoustic Doppler Current Profilers moored near the bottom at the $100 \mathrm{~m}$ and $200 \mathrm{~m}$ isobaths off Strahan, western Tasmania; winds resolved parallel to the coast, negative southward. The currents at each of the sites are averaged over the top, middle and bottom thirds of the water column.
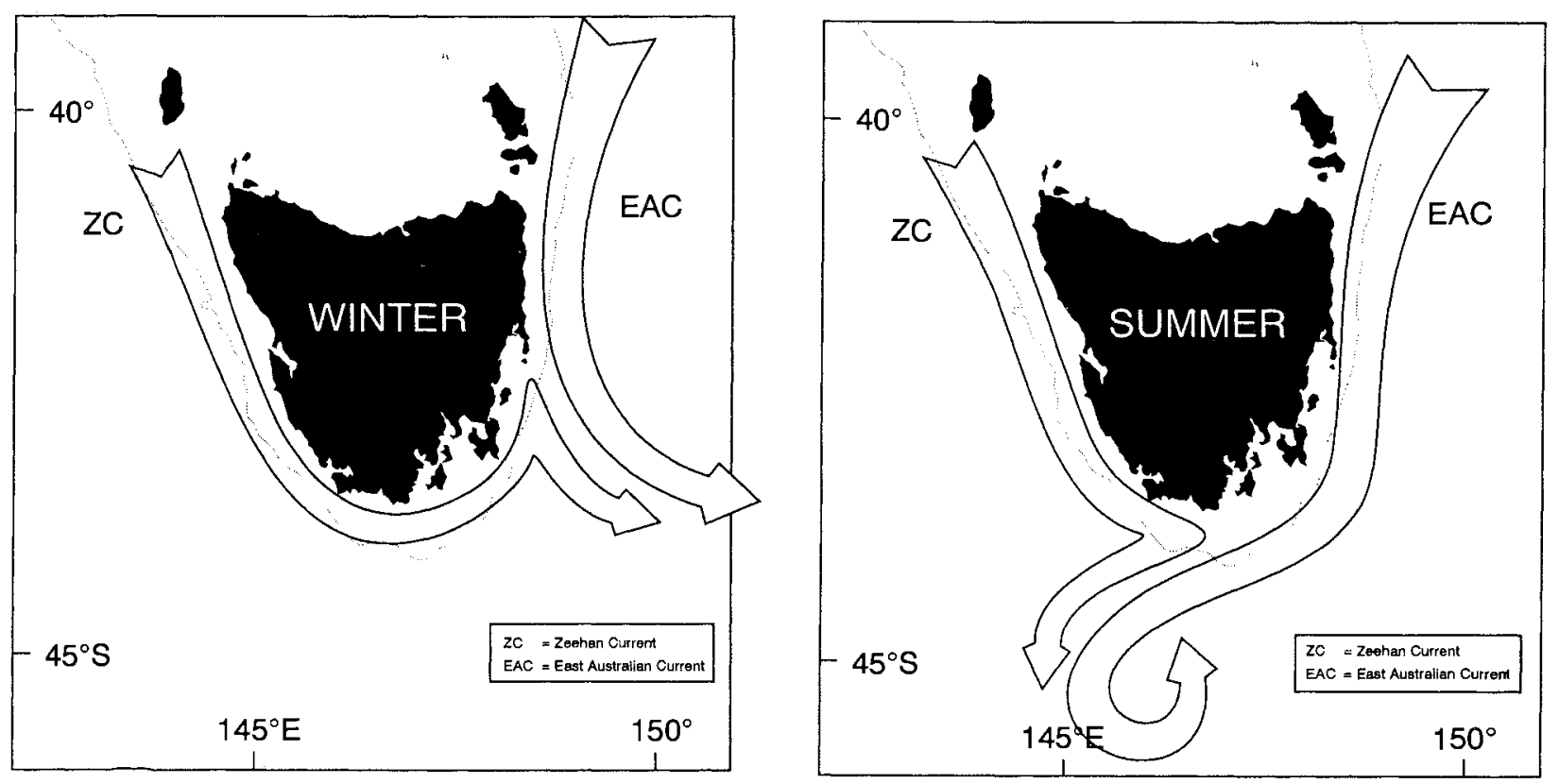

FIG. 7-Schermatic pictures for winter and summer showing the Zeehan Current off western Tasmania and its interaction with the East Australian Current. 


\section{CONCLUSION}

The interplay of the Zeehan and East Australian Currents that first emerged from the drifter work is summarised in the winter and summer schematic diagrams in figure 7 . These appear to be supported by the additional data types presented here. We have used the name Zeehan Current to mean the current on the outer half of the western continental shelf and upper slope, even though Baines et al. (1983) referred only to the slope when they coined the name; they had no data on the shelf. Along southeastern Tasmania, the Zeehan Current appears mainly confined to the shelf as a relatively low salinity feature. The winter maximum of the Zeehan Current that appears in our moored current measurements agrees with the winter maximum that was observed with moored current meters by Lyne \& Thresher (1994) in the same region.

\section{REFERENCES}

Baines, P.G., Edwards, R.J. \& Fandry, C.B., 1983: Observations of a new baroclinic current along the western continental slope of Bass Strait. Aust. J. Mar. Freshw. Res. 34: 155157.

EDWards, R.J. \& EMERY, W.J., 1982: Australasian Southern Ocean frontal structure during Summer 1976-1977. Aust. J. Mar. Freshw. Res. 33: 3-22.

Harris, G., Nilsson, C., Clementson, L. \& Thomas, D., 1987: The water masses of the east coast of Tasmania: Seasonal and interannual variability and the influence on phytoplankton biomass and productivity. Aust. J. Mar. Freshw. Res. 38: 569-590.
International Oceanogiraphic Tables, 1981: UNESCO Tech. Pap. in Marine Science 39.

Koninklijk Nederlands Meteorologisch Institut, 1949: Indian Ocean, Seas around Australia. Oceanogr. Meteorolog. Data 124. De Bilt.

Lyne, V.D. \& Thresher, R.E., 1994: Dispersal and advection of Macruronus novaezealandiae (Gadiformes: Merlucciidae) larvae off Tasmania: Simulation of the effects of physical forcing on larval distribution. In Sammarco, P.W. \& Heron, M.L. (Eds): THE BIO-PHYSICS OF MARINE LARVAL DISPERSAL. Coastal and Estuarine Studies 45. American Geophysical Union, Washington, DC: ch. 6, 109-136.

McMilisn, L. M. \& Crosby, D.S., 1984: Theory and validation of the multiple window sea surface temperature technique. J. Geophys. Res. 89: 3655-3661.

Newell, B.S., 196I: Hydrology of south-east Australian waters: Bass Strait and New South Wales tuna fishing area. CSIRO Div. Fish. Oceanogr. Tech. Pap. 10: 22 pp.

NEWELL, B.S., 1974: Distribution of oceanic water types off south-eastern Tasmania, 1973. CSIRO Div. Fish. Oceanogr. Rep. 59: 15 pp.

Nilsson, C.S. \& TildisLey, P.C., 1986: Navigation and remapping of AVHRR imagery. In Prata, A.J. (Ed.): IST AUSTRALIAN AVHRR CONFERENCE. Perth. CSIRO (Australia) Division of Groundwater Research: 286-298.

ScHotT, G., 1935: GEOGRAPHIE DES INDISCHEN UND STILLEN OZEANS. Verlag von C. Boysen, Hamburg: 413 pp.

VAUX, D. \& OLSEN, A.M., 1961: Use of drift bottles in fisheries research. Aust. Fish. Newsl. 20: 17-20.

WoOD, E.J.F., 1954: Dinoflagellates in Australian waters. Aust. J. Mar. Freshw. Res. 5: 171-351.

(accepted 29 August 1999) 